This PDF is a selection from a published volume from the National Bureau of Economic Research

Volume Title: The Great Inflation: The Rebirth of Modern Central Banking

Volume Author/Editor: Michael D. Bordo and Athanasios Orphanides, editors

Volume Publisher: University of Chicago Press

Volume ISBN: 0-226-006695-9, 978-0-226-06695-0 (cloth)

Volume URL: http://www.nber.org/books/bord08-1

Conference Date: September 25-27, 2008

Publication Date: June 2013

Chapter Title: Great Inflation and Central Bank Independence in Japan

Chapter Author(s): Takatoshi Ito

Chapter URL: http://www.nber.org/chapters/c9166

Chapter pages in book: (p. 357 - 387) 


\title{
Great Inflation and Central Bank Independence in Japan
}

\author{
Takatoshi Ito
}

\subsection{Introduction}

The Bank of Japan (BOJ) was born in 1882, only after the new Meiji government experimented unsuccessfully with transplanting the national banking system (without a central bank) from the United States. The government, after some unpleasant inflation under the national banking system, decided to adopt the central banking system modeled after the Belgium central bank. During more than 125 years of its uninterrupted history, the Bank of Japan saw three episodes of high inflation, defined by more than 20 percent of Consumer Price Index (CPI) inflation rate: (a) 1917 to 1919, the World War I years; (b) 1945 to 1949, immediately after the end of World War II; and (c) 1973 to 1974 , the first oil crisis. ${ }^{1}$ See table 7.1 for details. The

Takatoshi Ito is dean of and professor in the Graduate School of Public Policy at the University of Tokyo, a faculty fellow of the Centre for Economic Policy Research (CEPR), and a research associate of the Tokyo Center for Economic Research (TCER) and of the National Bureau of Economic Research.

This chapter was written for the conference on the Great Inflation. The author is grateful to comments on earlier versions by editors, a discussant, anonymous referees, Michael Bordo, Frederic Mishkin, and Athanasios Orphanides. The author has also benefited from detailed comments by Shigenori Shiratsuka, Masato Shizume, and other participants of a seminar at the Bank of Japan in July 2009. In addition, the author is grateful to many economists and executives, currently and in the past, of the Bank of Japan over the past three decades. Any remaining errors are those of the author. For acknowledgments, sources of research support, and disclosure of the author's material financial relationships, if any, please see http://www .nber.org/chapters/c9166.ack.

1. This can be taken as support to a view that, in the very long run, monetary discipline has been maintained in Japan since the 1880s, except for a few episodes. A more direct test of monetary neutrality in the long run was carried out by Oi, Shiratsuka, and Shirota (2004). 
Three episodes of high inflation

\begin{tabular}{lll}
\hline & CPI $(\%)$ & WPI $(\%)$ \\
\hline \multicolumn{3}{c}{ Episode I } \\
1917 & 22.7 & 25.8 \\
1918 & 34.6 & 31.0 \\
1919 & 33.0 & 22.5 \\
& Episode II & \\
1945 & $\mathrm{n} / \mathrm{a}$ & 51.1 \\
1946 & $\mathrm{n} / \mathrm{a}$ & 364.5 \\
1947 & $\mathrm{n} / \mathrm{a}$ & 195.9 \\
1948 & 83.0 & 165.6 \\
1949 & 31.7 & 63.3 \\
& Episode III & \\
1974 & 23.3 & 31.4 \\
\hline
\end{tabular}

Source: See Ito (1997). n/a = not available.

Note: Author's calculation.

first episode reflected the export boom during World War I. ${ }^{2}$ The second episode, when prices increased more than 200 times in a few years, was a result of the devastation of productive capacity and deficit financing cum monetization, which followed the end of World War II. So the 1973 to 1974 episode was the only example of high inflation unrelated to a war in which Japan was involved.

The main focus of this chapter is to examine the third episode of high inflation, when the CPI inflation rate remained above 10 percent from May 1973 to September 1975, with a spike up to 23 percent in 1974. (The inflation rate is defined as the percentage increase of CPI over the same month of the preceding year.)

It is commonly argued that the oil crisis was the culprit to blame for the 1973 to 1975 high inflation. However, the inflation rate already reached 10 percent several months before the Middle East crisis, which occurred in October $1973 .{ }^{3}$ The oil crisis only aggravated, though very badly, an inflationary spiral that was already in progress.

Reasons for the great inflation of 1973 to 1974 are the following: first, in late 1972, the Bank of Japan underestimated the strength of the economy and potential of prices to rise quickly. Second, there was a strong resistance against yen revaluation/appreciation. This was particularly true between December 1971, when the Smithsonian Agreement was reached, and Feb-

2. Shizume (2002) examines monetary policy in the interwar period, using the Taylor rule. He concludes that monetary policy was amplifying rather than mitigating domestic cycles due to consideration of the stability of the exchange rate, throughout the periods under the gold standard, 1897 to 1913 and 1930 to 1931; and managed exchange rate regime, 1913 to 1929; and after 1932 .

3. Seminal work that pointed out that monetary easing, or excess liquidity, existed before the oil price jump of October 1973 were Komiya (1976; 1988, ch. 8) and Komiya and Yasui (1984). 
ruary 1973, when the yen was finally floated. The pressure for appreciation prompted interventions by the monetary authorities in terms of selling yen, which added yen liquidity to the market, promoting inflation. Politicians also voiced their dislike of yen appreciation, and some of them were calling for stopping yen appreciation at any cost. The bank lowered the official discount rate (ODR) - that was the policy rate then - in June 1972, when recovery in output had already become obvious. Third, Mr. Kakuei Tanaka became prime minister (PM) in July 1972, advocating large fiscal spending. There was strong pressure from his government to keep the interest rate from rising. It was a regular practice in the 1960s and 1970s that any interest rate change was subject to preliminary discussion with and a tacit approval of the government and prime minister, before actually being decided in the Policy Board (in charge of monetary policy). The Monetary Policy Committee was not functioning as an independent decision-making body at all. (Details of pressure from politicians will be explained in later sections.)

With political pressure, it was not until April 1973 that the ODR was raised. By that time, the CPI inflation rate was exceeding 9 percent. The first three (out of five) interest rate hikes in 1973 were too little and too late. By the time of the oil price hike of October 1973, the fight against inflation had already been lost. Both headline and core CPI inflation rates rose above 20 percent by the beginning of 1974 .

A panic-like chaos resulting from high inflation in 1974 finally convinced the bank and politicians to apply strong tightening. ${ }^{4}$ The ODR was raised from 4.25 percent to 9 percent, in five steps, in 1973. However, the interest rate level stayed well below the inflation rate throughout this episode. The real interest rate, measured by the difference between ODR and CPI headline inflation rate, was on average minus 5.6 percent in 1973, and minus 14.1 percent in $1974 .{ }^{5}$ Disinflation in 1974 was accompanied by a sharp output decline, a great sacrifice. The negative growth rate of 1974 was the first since 1950 .

There are three possible hypotheses to explain the bank's soft stance toward inflation. The first hypothesis is that the Bank of Japan did not know that the inflationary pressure was building in the economy. Examination of a memoir (Nakagawa 1981) and the bank historical archives (Bank of Japan 1986) reveal that this was probably not the case. The second hypothesis is that the Bank of Japan knew that the inflationary risk was rising, but did not seek tightening in time because of a fear of being turned down. The third hypothesis is that although the Bank of Japan knew of the risk and

4. Wholesalers were believed to have bought and hoarded goods. Consumers also bought in bulk to guard themselves from future inflation. These actions shrank supply quickly and contributed to further price increases. One widely reported story was that toilet paper would be missing from store shelves, so consumers, in a panic, rushed to supermarkets to purchase toilet paper-clearing the store selves, indeed.

5. Even when the overnight call rate was used instead of ODR, the real interest rate was minus 4.4 percent in 1973 and minus 10.6 percent in 1974. 
attempted to tighten, the tightening proposal was rejected by the government. The relationship with the government (especially prime ministers, as well as finance ministers) in 1972 to 1973 holds a clue. A close examination of the events reveals that the truth is somewhere between the second and third hypothesis.

After the 1973 to 1974 episode of high inflation that was widely attributed, in part, to a mistake of the Bank of Japan, one might think that the Bank of Japan would have been discredited. On the contrary, the bank came out of the episode with a stronger voice. The bank argued that if its recommendation to tighten monetary policy was to be overruled, the tragic experiences of 1972 to 1973 would be repeated. With this logic, the Bank of Japan obtained de facto independence. The ODR was raised much earlier in 1979 to 1980 , the second oil crisis, than in 1973. Even more remarkable here was that the ODR was raised during the months of a budget debate in the Diet - between January and March - which up to that time was politically inconceivable. ${ }^{6}$ The real interest rate remained positive in 1979 to 1980 , in contrast to being hugely negative in 1973 to 1974 . The real interest rate measured by the difference between the ODR and CPI headline inflation rate was on average 1 percent in 1979 and 0.4 percent in 1980, while the real interest rate of the call rate was 2.2 percent in 1979 and 3.2 percent in 1980. As a result, even with sharp oil price increases in 1979 to 1980, the inflation rate in Japan remained moderate, peaking at 8.7 percent.

The rest of this chapter is organized as follows. The next section reviews the 120-year history of inflation in Japan. Section 7.3 describes the economic events and political developments as well as monetary policy actions, which resulted in the Great Inflation of 1972 to 1974 . The monetary policy during this period is considered to be a mistake. ${ }^{7}$ Section 7.4 describes why the Bank of Japan gained monetarist rhetoric and de facto independence after the mistake of 1972 to 1973 . Section 7.5 reviews no-inflation experience during the second oil crisis, 1978 to 1980 . Section 7.6 will be devoted to some econometric analysis to substantiate the arguments in the preceding sections. Section 7.7 concludes the chapter.

\subsection{Great Inflation of 1973 to 1974}

\subsubsection{Transition from the Bretton Woods to Free Floating}

The collapse of the Bretton Woods regime in August 1971 suddenly freed the Bank of Japan from conducting monetary policy solely to maintain the balance of payments by controlling domestic demands. Theoretically the

6. The reason for the hesitation of ODR changes during the budget process was that it would make budget assumptions outdated, while a budget bill could not be changed easily.

7. See Ito $(1992,125-27)$ for an earlier description of the "mistake." 
exchange rate could move freely to adjust imports and exports, and the Bank of Japan could concentrate its policy objectives to domestic prices. But, this did not happen, at least not until February 1973.

After some chaotic trading in the yen/dollar market and gradual appreciation of the yen after the collapse of the Bretton Woods regime, the G10 countries agreed in December 1971 to a new parity with a narrow band with fluctuation plus/minus 2.25 percent. The yen had appreciated gradually from 360 yen to 315 yen per dollar by the mid-December 1971 . Under the Smithsonian Agreement of December 18, 1971, the central rate for the yen/dollar rate was determined, after tough negotiation, to be 308 yen/dollar, a 16.88 percent revaluation (according to the International Monetary Fund [IMF] definition) from the Bretton Woods rate of 360 yen/dollar.

The Smithsonian rate of 308 yen/dollar was regarded by many in Japan as a dangerously appreciated yen level. The export industries, particularly shipbuilding, were considered to be vulnerable. Guarding against further appreciation became a new national objective. As the yen had stuck at the most appreciated level (ceiling) of the Smithsonian band in 1972, monetary policy and fiscal policy were conducted to stimulate the domestic economy so that imports would increase and the trade surpluses would come down. Even if inflation would result from increasing domestic demand, that would not be a problem, politicians insisted. Political pressure to keep monetary policy relaxed was strong, but no dissenting voice from the Bank of Japan was heard in public.

\subsubsection{The "Mistake": Overview}

Movements of the inflation rates-CPI and Wholesale Price Index (WPI) - and the interest rates_-ODR and call rate-from 1971 to 1975 are shown in figure 7.1, where inflation variables are defined as a change over the same month of one year earlier. Table 7.2 shows industrial production, M2 growth rate, and yen/dollar rate, as well as CPI and WPI inflation. There were little cautionary signs of inflation until the summer of 1972, the CPI inflation rate being at around 5 percent, and slightly declining, and the WPI inflation rate close to zero. However, the WPI started to increase in the summer of 1972, and quickly reached 5 percent, the level of CPI inflation rate, by November 1972. The sharp increase in the WPI was considered to be an indication of future inflation in the CPI.

In June 1972, the interest rate was cut to stimulate the economy. According to Nakagawa (1981), this rate cut was first planned in April, but delayed for political reasons. This will be explained in detail later. By the time of implementation, it was way behind the curve, since the WPI inflation rate started to increase and industrial production started to show signs of recovery.

The WPI inflation rate continued to accelerate, and reached 11 percent by April 1973, while the CPI inflation rate reached 9.4 percent by April 1973. In 


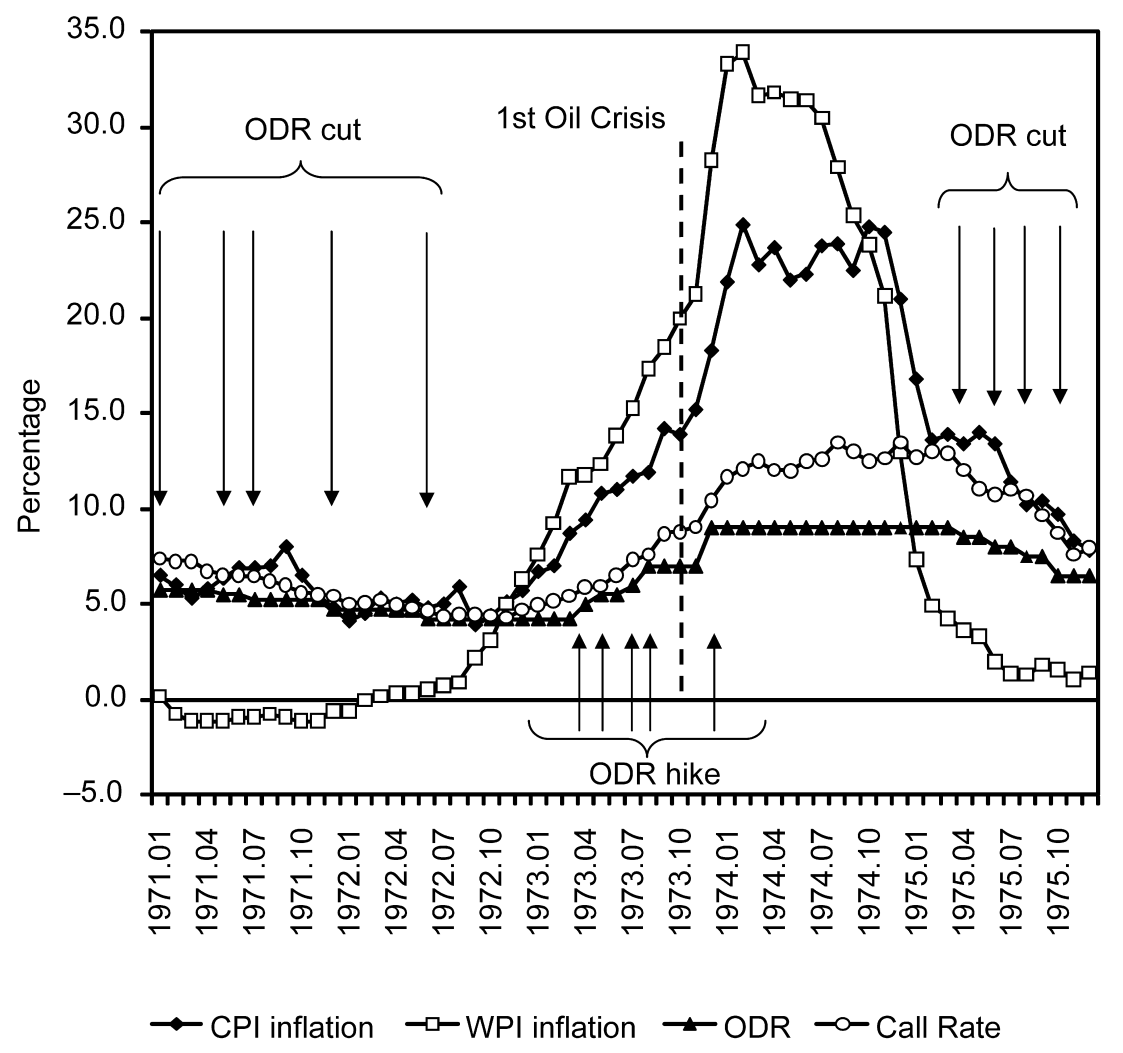

Fig. 7.1 Great Inflation of 1973-1974

April 1973, the Bank of Japan raised its policy interest rate (ODR) for the first time since the collapse of the Bretton Woods system.

Because the inflation rate rose sharply and exceeded 10 percent by summer 1973 and there were some signs already a year earlier, the interest rate cut of June 1972 was a "mistake." 8 By the same reasoning, the absence of

8. Hetzel (1999) provides the overview of Japanese monetary policy during the period from 1970 to 1998 . He argues that the Bank of Japan had little room to make decisions until the fixed exchange rate was abandoned. It is true that under the Bretton Woods regime (which ended in August 1971), there could not be totally autonomous monetary policy — independent from the US monetary policy — but since substantial capital controls were in place, the interest rate could be deviated from the United States. However, Japanese monetary policy could not be totally autonomous due to the balance of payment (BOP) constraints (see Ito 1992, ch. 5). In sum, monetary policy had a room to maneuver due to capital controls, but there was an overall BOP constraint. After August 1971, there were substantial policy options, including how much appreciation and fluctuation of the yen to be tolerated, how much inflation rate to be tolerated, how much capital liberalization to be allowed. Before the Smithsonian Agreement - an attempt to fix the exchange rates at new rates with wider bands - the major countries were struggling with how much appreciation vis-à-vis the US dollar was to be tolerated, and Japan was not an exception. The Smithsonian Agreement, December 1971, was a result of 
Table 7.2 Prices and money prior to Great Inflation

\begin{tabular}{lcccccc}
\hline & $\begin{array}{c}\text { CPI } \\
\text { inflation }\end{array}$ & $\begin{array}{c}\text { WPI } \\
\text { inflation }\end{array}$ & $\begin{array}{c}\text { Industrial } \\
\text { Production }\end{array}$ & $\begin{array}{c}\text { M2 } \\
\text { growth }\end{array}$ & $\begin{array}{c}\text { Yen/dollar } \\
\text { rate }\end{array}$ & $\begin{array}{c}\text { Monetary policy } \\
\text { action }\end{array}$ \\
\hline 1972.01 & & & 1.3 & 25.1 & 312.23 & \\
1972.02 & & & 3.0 & 25.3 & 304.98 & \\
1972.03 & & & 3.9 & 26.1 & 302.44 & \\
1972.04 & & & 3.8 & 26.2 & 303.56 & \\
1972.05 & 5.2 & 0.4 & 8.3 & 25.5 & 304.44 & \\
1972.06 & 4.8 & 4.1 & -0.6 & 26.6 & 303.68 & Interest rate cut \\
1972.07 & 5.0 & 4.5 & 0.0 & 27.1 & 301.11 & \\
1972.08 & 5.9 & 5.3 & 0.2 & 26.4 & 301.10 & The yen/dollar \\
1972.09 & 3.9 & 5.0 & 0.4 & 26.9 & 301.10 & rate virtually \\
1972.10 & 4.4 & 3.2 & 10.6 & 27.8 & 301.10 & fixed \\
1972.11 & 5.1 & 5.0 & 11.4 & 28.5 & 301.10 & \\
1972.12 & 5.7 & 6.3 & 14.7 & 26.5 & 301.23 & \\
1973.01 & 6.7 & 7.6 & 17.1 & 26.1 & 301.96 & \\
1973.02 & 7.0 & 9.3 & 16.9 & 26.8 & 279.48 & \\
1973.03 & 8.7 & 11.6 & 16.5 & 26.9 & 265.26 & \\
1973.04 & 9.4 & 11.8 & 16.9 & 27.3 & 265.52 & Interest rate hike
\end{tabular}

Inflation acceleration $\leftarrow$ Output expands rapidly $\leftarrow$ Money growth had remained high

monetary tightening until the CPI inflation rate was near 10 percent in April 1973 showed that the bank was too slow to respond. Reasons for this mistake based on political economy are presented in the following.

Figure 7.1 also shows that after the Middle East Crisis of October 1973, both the CPI and WPI inflation rates increased sharply. The WPI inflation rate rose to near 35 percent, and the CPI near 25 percent by spring 1974 . This was the greatest peacetime inflation for Japan. Due to a very high inflation rate, wages rose sharply in 1974 as well as 1973, in order to compensate for an increase in living costs. Companies were enjoying profits from the demand stimulation of 1972 and 1973 (until the oil price shock, starting in October 1973). The inflation spiral was in place from mid-1973 to 1974. Oil prices tripled from July 1973 to January 1974, with the selective embargo by the Oil Producing Exporting Countries (OPEC). The sharp increase in imported oil prices aggravated the already high and increasing inflation rate.

While the CPI inflation rate above 20 percent was very high, the industrial production growth rate turned negative in 1974, as shown in figure 7.2. The real GDP growth rate became negative for the first time since 1955, when

hard negotiation groping for new constellation of fixed exchange rates. Japan accepted more than 16 percent appreciation, but probably that was too little. Since there was a wide band, theoretically, monetary policy had room to maneuver under the Smithsonian regime. However, the yen had stuck at the ceiling, before Japan decided to abandon the Smithsonian regime in February 1973, one month ahead of European countries. Hence, including the choice of abandoning the Smithsonian regime, there were policy choices between December 1971 and February 1973. It was certainly true that monetary policy was freed from US monetary policy after February 1973. 


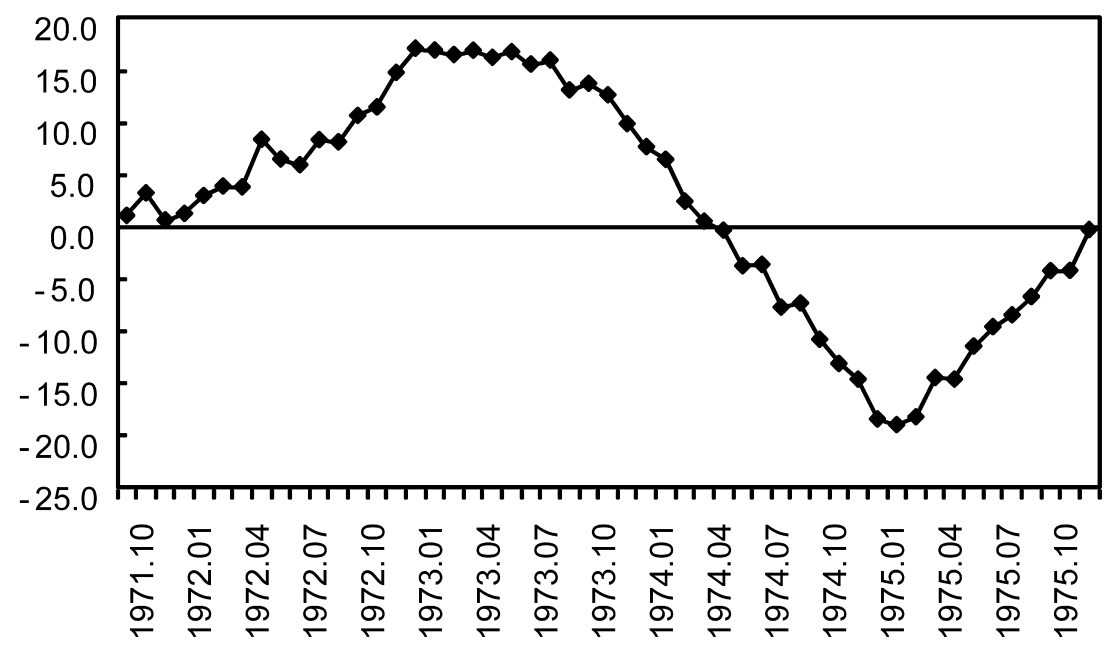

Fig. 7.2 Industrial Production growth rate $(y-y), 1971-1975$

GDP statistics became available. Table 7.3 shows GDP changes, quarter-toquarter annualized rates, and year-on-year growth rates. Table 7.4 shows the GDP growth rates. The year 1974 was typical of stagflation - a very high inflation rate with negative growth in output.

Table 7.3 and vertical lines in figure 7.1 show the timing of the monetary policy actions. The interest rate (ODR) was raised five times in the ninemonth period starting in April 1973. However, there was no action in 1974. Obvious questions are why tightening did not come earlier and why there was not more tightening in 1974 . We will answer these questions later.

Figure 7.3 shows movements of the CPI headline, CPI core (excluding fresh food), and CPI core-core (excluding food and energy-related). Since all three CPIs move together, it shows the role of energy was relatively small, in the run-up to the high inflation period of 1974 . There is a maximum 5 percent point difference between core and core-core, which is roughly the contribution of energy prices.

Negative growth in 1974 and quite depressed wage increase in 1975 were the reason that the inflation rate came down in the second half of 1974 and throughout 1975. The WPI inflation rate fell below 5 percent in the spring of 1975, and by the end of 1975, the CPI inflation rate fell below 10 percent. The great inflation of 1973 to 1974 was over, with a heavy sacrifice in output activities in 1974.

\subsubsection{Why Easing Went Too Far: The Mistake of June 1972}

As explained before, the necessity of lowering the ODR by 50 basis points on June 24,1972 , is highly questionable since the output had shown signs of recovery, and prices, particularly the WPI, also showed the sign of recovery. 


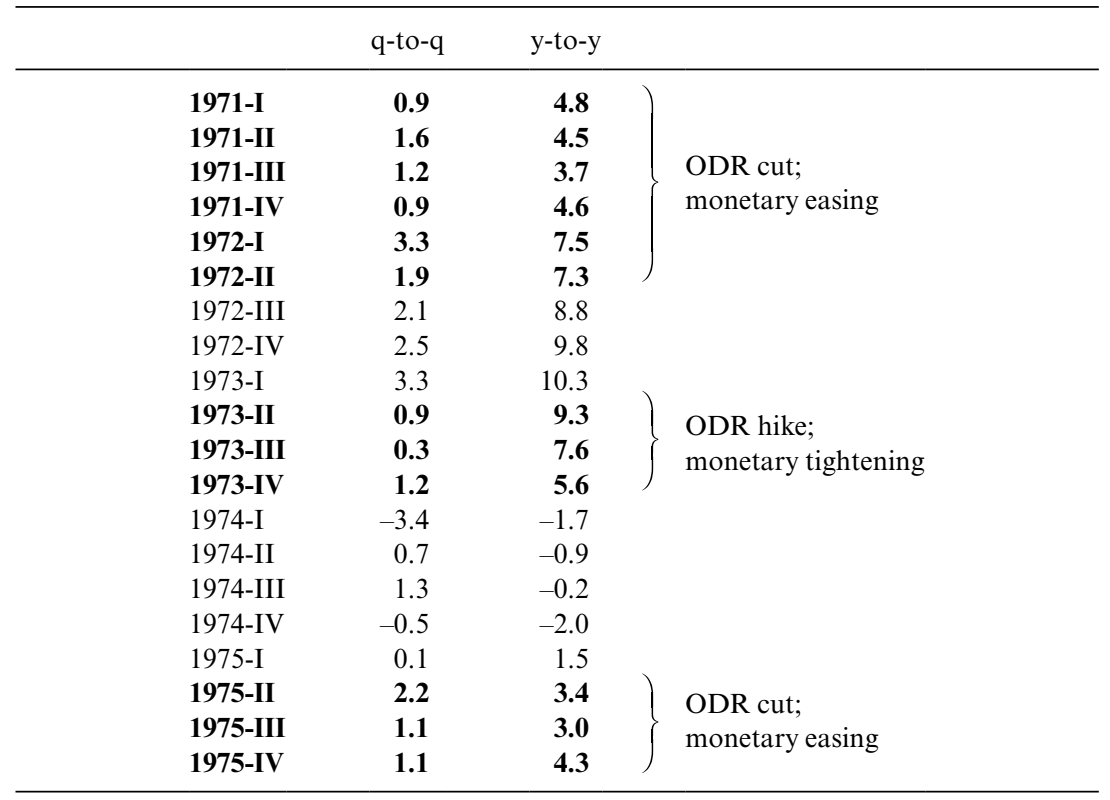

Table 7.4 Monetary policy actions and critical questions

\begin{tabular}{lcc}
\hline \multicolumn{3}{c}{ Official discount rate (\%) } \\
\cline { 2 - 3 } Date & \multicolumn{2}{c}{$1970-1975$} \\
\cline { 2 - 3 } yyyy.mm.dd & Change & New level \\
\hline 1970.10 .28 & -0.25 & 6.00 \\
1971.01 .20 & -0.25 & 5.75 \\
1971.05 .08 & -0.25 & 5.50 \\
1971.07 .28 & -0.25 & 5.25 \\
1971.12 .29 & -0.50 & 4.75 \\
$1972.06 .24^{\mathrm{a}}$ & -0.50 & 4.25 \\
$\mathbf{1 9 7 3 . 0 4 . 0 2}$ & $\mathbf{0 . 7 5}$ & $\mathbf{5 . 0 0}$ \\
$\mathbf{1 9 7 3 . 0 5 . 3 0}$ & $\mathbf{0 . 5 0}$ & $\mathbf{5 . 5 0}$ \\
$\mathbf{1 9 7 3 . 0 7 . 0 2}$ & $\mathbf{0 . 5 0}$ & $\mathbf{6 . 0 0}$ \\
$\mathbf{1 9 7 3 . 0 8 . 2 9}$ & $\mathbf{1 . 0 0}$ & $\mathbf{7 . 0 0}$ \\
$\mathbf{1 9 7 3 . 1 2 . 2 2}$ & $\mathbf{2 . 0 0}$ & $\mathbf{9 . 0 0}$ \\
1975.04 .16 & -0.50 & 8.50 \\
1975.06 .07 & -0.50 & 8.00 \\
1975.08 .13 & -0.50 & 7.50 \\
1975.10 .24 & -1.00 & 6.50 \\
\hline
\end{tabular}

${ }^{a}$ Was this necessary?

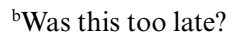




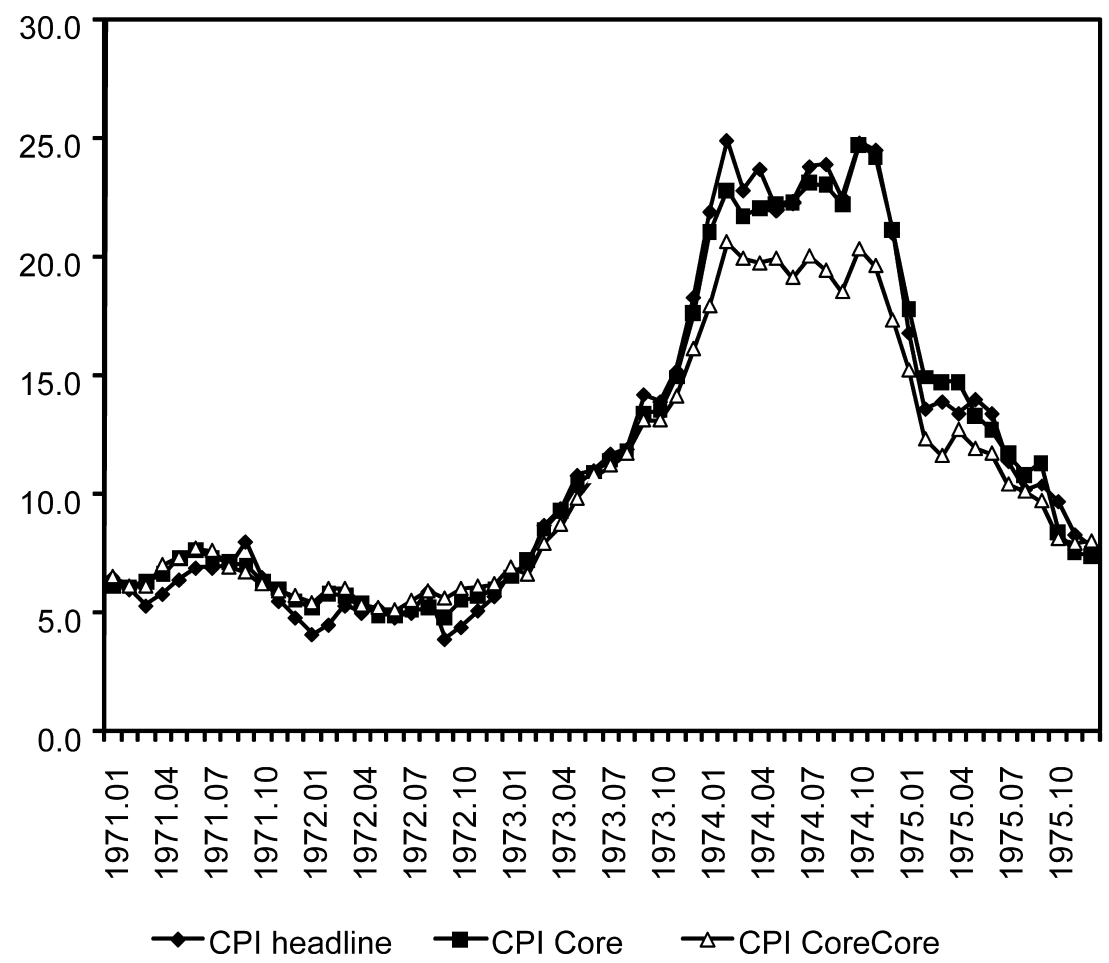

Fig. 7.3 Energy prices contributed to only a small part of Great Inflation

Bank of Japan (1986) and Nakagawa (1981), a former bank senior official, describes what really went on behind the scene over this period.

In April 1972, lowering the ODR was considered as a part of an anti-yen appreciation package of the government. Inside the BOJ, opinions were divided into two camps, one favoring lowering the ODR and the other considering the rate cut unnecessary. Governor Sasaki maintained to the press that it was not necessary. On May 10, Governor Sasaki met Prime Minister Sato, and the Governor was asked to consider lowering the ODR. On May 11, Governor Sasaki mentioned that the ODR would be lowered on the condition that the bank deposit rates would be lowered. Inside the bank, the proposal by the governor to lower the rate, although with one technical condition, was considered to be a surprise turnaround of his position. (See BOJ [1986, 381] for events on May 10 and 11.)

It took more than a month to decide on the deposit rate, because the Ministry of Posts and Communication, which oversaw the Postal Saving System, was opposed to the deposit rate cut. Finally, on June 23, the postal saving deposit rates were lowered, and the bank decided to lower the ODR.

This episode reveals three problems. First, the governor apparently was 
persuaded by the prime minister on the interest rate decision. Second, as all the private-sector interest rates were effectively linked to ODR, the ODR decision should seep into the system automatically. However, bank deposit taking and postal saving deposit taking competed for household deposits. Thus, the Ministry of Posts and Communication could effectively block the timely implementation. Third, between the government plan of April and the actual implementation, two months had passed. The wisdom of lowering the interest rate should have been reassessed by the Bank of Japan as well as by the government in June.

Nakagawa (1981) regrets that the bank (including himself) had not been courageous enough to scrap the plan for the interest rate cut, since between April and June, economic activity picked up considerably. He, however, thinks that once the political process forcing the Postal Saving System to lower the deposit rate had gone through the cycle, it was difficult to scrap it (Nakagawa 1981).

\subsubsection{Why Tightening Did Not Come Earlier}

With the government and the Bank of Japan pressing for domestic demand stimulation - again to avoid appreciation of the yen - in the first half of 1972, the wish was granted. In the second half of 1972, the economy was growing full steam. The GDP growth rate was increasing in the 9 to 10 percent range in the second half of 1972, and rose above 10 percent in 1973 (recall table 7.3); industrial production was increasing in the 10 to 15 percent range from mid-1972 to the end of 1972 . The CPI inflation rate was above 5.7 percent and WPI inflation rate was 6.3 percent in December 1972. It seems very natural that the Bank of Japan would react to raise the interest rate as early as October 1972, and as late as December 1972. Why was the ODR not raised until April 1973?

The simple answer for a delayed reaction to inflation signals was again actual and potential political pressure. The economy indeed became strong and inflation pressure mounted by the end of 1972. The ODR was not raised until April 1973.

The government decided to have a fiscal expansion package for the 1972 fiscal year budget (April 1972 to March 1973) under Prime Minister Sato. The 1973 fiscal year was also intended to maintain fiscal stimulus. On July 7 , 1972, Mr. Tanaka became prime minister. He won the presidency of the Liberal Democratic Party - hence automatically guaranteed to become prime minister - on the platform of "Reconstruction of the Japanese Archipelago"- large public works to build a network of road and railroad infrastructure. He announced an additional fiscal spending program in August. In October a supplementary budget and a second additional plan for a fiscal investment program was announced. He was very popular among the voters. It was clear that he would be opposed to the rate hike. The Bank of Japan felt that it would not be possible to seek a rate hike. On 
November 9, PM Tanaka reiterated a strong opposition to yen revaluation (BOJ 1986, 403)

On November 13, the House of Representatives was dissolved, and on December 11, 1972, the general election took place. According to Bank of Japan (1986) and Nakagawa (1981), the Ministry of Finance told the Bank of Japan not to consider even the appearance of a policy change during the election period.

Right after the election, the budget discussion started in the Diet and the budget debate and votes continued until March 13, 1973. Traditionally no monetary policy changes were made during the budget process, because that would affect the assumption of the budget. This time, tradition was kept.

On February 14, 1973, the yen was floated (earlier than the European currencies) as a result of heavy pressure for yen appreciation. In March 1973, currency speculation became widespread among the European currencies, resulting in free floating (the end of the Smithsonian).

When the budget process was over, and the fixed-exchange rate fetter was broken, the Bank of Japan got an approval for a rate hike. On March 31, 1973, the approval was given (and implemented two days later) in a chat between the finance minister and governor in the corridor of the Diet (BOJ 1986).

Eight months of selecting a prospending prime minister, the dissolution of the Diet, and the budget process in the Diet explains the tardy implementation of the rate hike. There was an explicit approval of inflation if it would contribute to keep the nominal exchange rate within the approved range under the Smithsonian rate. On August 9, 1972, Ministry of International Trade and Industry (MITI) Minister Nakasone mentioned that he preferred domestic inflation to yen appreciation (BOJ 1986, 401). He said, "Japan is forced to choose between another yen revaluation and adjustment inflation. I think another yen revaluation should be definitely avoided; hence the economic activities should be stimulated." The inflation to avoid appreciation was named "adjustment inflation." Indeed, one way to achieve real exchange rate appreciation - which may be required to prevent the trade surplus from increasing - is inflation. Of course, inflation carries high costs of adjustment and distortions, and is an inferior policy compared to appreciation of the nominal exchange rate. However, this view was not shared among politicians at the time.

The step of the April 1973 rate hike, 75 basis points, was unusually high, probably reflecting the fact that the bank was behind the curve. Three other rate hikes - May $30(+0.50)$, July $2(+0.50)$, Aug $29(+1.00)$ - followed in a hurry (recall table 7.4 and figure 7.2). However, the inflation rate continued rising. With the news of the Middle East War breaking out on October 6, 1973, the inflation rate was already at a dangerously high level, with the CPI at 15 percent and the WPI at 20 percent. Inflation rates shot up after October-some direct result of increasing oil prices, and some indirect, but 
immediate, effects of speculative inventory hoarding and panic buying. The Bank of Japan decided to raise ODR by 200 basis points on December 22, to put maximum pressure against inflation.

The real interest rate remained negative from October 1972 until mid1975. The period from October 1972 to mid-1974 is characterized as widening the gap (more negative interest rate) and accelerating growth - a clear sign of being behind the curve. The real interest rate remained negative until mid-1975. Tightening was too little, too late throughout 1973.

A crucial question is whether the Bank of Japan knew of the danger of postponing the rate hike and if so, whether the bank sought after the rate hike even with risk of clashing with the government. The Bank of Japan (1986, 409-11) described the inside thinking at the time. As the pace of inflation picked up, the Bank of Japan decided to push for the ODR hike in February 1973. The yen was floated on February 14 and appreciated substantially. This removed one constraint on monetary policy. However, this produced a political push for stimulus. Again, it was still in the budget process, which was the politically sensitive time of the year to change the interest rate, so that the Bank of Japan tried to raise the reserve ratio rather than the interest rate. The increase in the reserve ratio was decided on March 2, and implemented on March 16. The Policy Board chair noted, "The economy recently has become more active; prices are rising high; and corporate investment has become strong, ... in order to restrain the lending of financial institutions and manage aggregate demand appropriately, ... the reserve ratio was decided to be raised, upon approval of the Minister of Finance" (110-11). The budget bill was passed in the House of Representatives on March 13, and Prime Minister Tanaka admitted on March 16 the need for a policy switch to monetary tightening and fiscal adjustment for restraining aggregate demand. This gave an approval for a policy action toward tightening. The ODR hike was decided on March 31 (Saturday) and implemented on April 2, "in order to restraint aggregate demand." In addition, quantitative restraint on lending from city banks was strengthened.

There is not much of a trace of a struggle between the bank and the government prior to February 1973, reading through Bank of Japan (1986). The bank was probably too self-restrained, or gave up on fighting against the Ministry of Finance as well as inflation.

\subsubsection{Political Economy}

Let us recap the Great Inflation episode. There were two kinds of major mistakes committed in 1972 and 1973: too much easing, especially the June 1972 rate cut; and too little and too late tightening that started in April 1973. Possible reasons for the mistake are as follows:

1. Was the Bank of Japan targeting price stability?

2. Did the Bank of Japan fail to forecast the inflation rate pick up? 
3. Did the government put pressure on the Bank of Japan to stimulate the economy?

4. Did the Bank of Japan have courage to disagree?

Answers in short are as follows based on the documents that examined the decision making of the 1970s.

1. No, the Bank of Japan did not put price stability as priority number one.

2. Yes, the Bank of Japan knew prices were rising.

3. Yes, the Bank of Japan was under pressure from the government to lower and keep low the interest rate, and could not resist the pressure.

4. No, the Bank of Japan did not fight back.

Let us elaborate on these points in the following subsections.

\section{Lack of Clear Policy Objective under the Managed Float}

Recall that the average inflation rate in Japan during the 1960s was 1.3 percent measured in WPI and 5.7 percent measured in CPI, and the economy did fine, growing at more than 10 percent a year and with current account remaining surplus. Thus, it is not surprising that policymakers in 1971 and 1972 were not alarmed by the CPI inflation rate at around 6 percent, especially when the WPI inflation rate was at around 0 percent. The ODR was lowered four times between October 1970 and July 1971, in the hope of stimulating domestic demand further and averting an appreciation of the yen. These actions were under the Bretton Woods regime, and quite understandable, if maintaining the exchange rate regime was the superior objective.

After the Bretton Woods regime collapsed, the government and the Bank of Japan decided to resist pressure for strong yen appreciation pressure by heavy intervention. However, they underestimated the strength of the Japanese manufacturing industries. By putting a policy objective to moderate yen appreciation, inflation was tolerated.

\section{Lack of Political Independence}

The Bank of Japan Law in the 1970s (until 1998) did not give the bank a policy objective of price stability or legal independence from the Ministry of Finance. The objective of the bank in the law was to "maximize the potential of the economy," and the bank policy was under the direction of the minister of finance. On the other hand, the interest rate was supposed to be decided by the Policy Board (in charge of monetary policy) of the Bank of Japan that includes appointments from outside the bank. Theoretically, the Policy Board can make interest rate decisions that may be opposed by the government. The government has the power to replace Policy Board members as well as the governor. In reality, the bank senior executives sought 
after a tacit prior approval from the government over interest rate decisions, and the Policy Board had become just an automatic approving body of the bank executives. Getting approval of the interest rate changes was tricky. It often depended on the relationship between the governor and the minister of finance, or between the governor and the prime minister

Later in 1998, the Bank of Japan Law was revised. Cargill, Hutchison, and Ito $(1997,2001)$ describes the history and legal details of the Bank of Japan laws, with a comparison of scores of legal independence between the old and new laws.

What could the central bank have done in the absence of independence? Without independence, the governor could be replaced at the will of the government, and so could members of the Policy Board. It was tradition that the change in monetary policy had to be negotiated with the Ministry of Finance (and prime minister), although by law the Policy Board at the Bank of Japan could decide on its own power. Even lowering the interest rate was difficult because the Ministry of Posts and Telecommunications tended to oppose lowering the deposit rate. Increasing the interest rate, of course, was much harder. Could the governor put his job on the line to disagree with the government? Maybe that was not the Japanese style.

\subsection{Monetarist Rhetoric for Independence}

One lesson that the Bank of Japan learned from the mistake of creating high inflation in 1973 and 1974 was to enhance de factor independence. To develop more theoretical underpinning for controlling inflation was one lesson, and to assert the danger of inflation, when met with pressure from the government, was another. If the future inflation can be credibly warned with some indicators, that would be persuasive.

The Bank of Japan published a study in 1975 on the importance of monetary aggregate, $\mathrm{M} 2+\mathrm{CDs}$, in predicting future inflation and output, and announced a new monetary policy procedure in $1978 .{ }^{9}$ Beginning in July 1978, the Bank of Japan made it a regular procedure to announce a "forecast" of the growth rate of the average outstanding balance of money $(\mathrm{M} 2+\mathrm{CDs})$ relative to the same period in the previous year, at the beginning of the quarter. For example, the forecast for monetary growth in the first quarter of 1985 over the first quarter of 1984 was announced at the beginning of the first quarter of 1985 . There are two important features for this procedure. First, the forecast included the will of the Bank of Japan: "[T]he policy actions of the Bank of Japan itself are included in the determination of these forecasts, and in this sense the forecasts represent increases in the money supply that the Bank of Japan is willing to permit" (Suzuki

9. See Bank of Japan, $(1975,1988)$ for their description of the procedure and assessments. 
$1987,331)^{10}$ Second, three quarters out of four were already history in the announced annual growth rate. The forecast represents an average of three quarters' realized monetary growth and the current quarter's projected monetary growth. Therefore, the will to change in money is concentrated on the current quarter.

If the monetary growth rate is an indicator for warning future inflation, monetarism rhetoric can be used in the debate against those who argue otherwise. Although the Bank of Japan did not seem to actively use the monetarism rhetoric against political pressure, the monetary indicator may have contributed to confidence among the bank economists internally.

At the time, a monetarist thinking had a strong influence among central bank researchers as well as academics. The Bank of Japan must have thought that there was a high correlation between $\mathrm{M} 2+\mathrm{CDs}$ and future nominal GNP, and that it could relatively easily control M2 + CDs via monetary policy instruments. Thus, using $\mathrm{M} 2+\mathrm{CDs}$ as an intermediate target, the bank could target low inflation rate and full-employment output at the same time.

The new procedure had rhetoric of distinct monetarism flavor. In fact, Milton Friedman (1985b) praised that the Bank of Japan followed monetarist rule that he had advocated. ${ }^{11}$ By keeping the monetary growth rate steady, say at $k$ percent, then output would be stabilized and the inflation rate would be kept low (near $k$ percent). The Bank of Japan has been the least monetarist central bank in its rhetoric, and the most monetarist in its policy. It has also achieved the best results. However, Suzuki (1985) was more cautious. He branded the Japanese monetary policy of the time as "eclectic gradualism," which is a position between Keynesian fine-tuning and a monetarist $k$ percent-growth rule.

A decade later, Suzuki (1985) observed that the money-supply growth rate was gradually reduced, and so was the nominal-GNP growth rate- - but without interfering with the real-GNP growth rate; moreover, fluctuations in the money supply have decreased. ${ }^{12}$ This means that the gradual decrease in the money-supply growth rate reduced inflation without reducing economic growth; that is, no trade-off between inflation and potential growth.

Was the successful Bank of Japan policy a $k$ percent rule? According to Ito $(1989,1992)$, the Bank of Japan did not practice the $k$ percent-growth rule preached by monetarists in the following details of implementation. If the $k$ percent rule had been implemented, then higher-than-forecasted growth in money should have been followed by lower-than-trend growth in

10. See Ito (1989) for more detailed descriptions and examination of the Bank of Japan "forecasts" of monetary aggregate growth rates.

11. Milton Friedman (1985a) was very critical of the Federal Reserve under Chairman Paul Volcker in its implementation of the 1979 policy to target the growth rate of monetary aggregate (M1) in an attempt to fight inflation.

12. See also Cargill, Hutchison, and Ito (1997, ch. 3) for the updated discussion. 
money, to maintain the long-run growth rate of $k$ percent by offsetting the upward deviation.

However, it was found that when the actual monetary growth rate deviated from its forecast rate, the target rate of the following period (quarter) was most likely to be adjusted toward the actual growth rate. That is, if the actual growth rate was higher than the target rate in quarter $T$, the target rate of quarter $T+1$ was higher than the target rate in quarter $T$. In addition, the target was unbiased in the sense that the mean of the forecast error was zero-the "forecasts" were rational expectations.

The observed facts are not consistent with monetarist practice. If the $k$ percent rule had been taken seriously, the target rate for quarter $T+1$ should move in the opposite direction of the deviation so that $k$ percent growth in the money stock could be maintained in the long run. That is, if the actual rate was higher than the target rate in quarter $T$, then the target rate of quarter $T+1$ should be lower than the target rate in quarter $T$, in order to compensate for the unexpected increase (see Ito 1989).

Thus, despite praise from monetarists, the monetary policy of the Bank of Japan cannot be judged to have been practicing monetarism as defined by the $k$ percent rule. However, the fact that the inflation rate was brought down gradually without affecting the trend growth rate was praised as a successful implementation of monetary policy with monetary aggregate emphasis (see Suzuki 1985, 1987). It is conceivable that the monetary growth emphasis from 1978 to the mid-1980s gave some weapon of rhetoric in fighting against pressure from the government (see Ito 1992, chapter 5).

The emphasis on monetary growth rate was more or less terminated after 1987, when the monetary aggregate growth rate became much higher than forecasts consistently, most likely from the instability of money demand due to rapid financial liberalization at the time.

\subsection{No Great Inflation from 1979 to 1980}

\subsubsection{Overview}

Another oil crisis came at the end of the 1970s. If the oil crisis was a culprit of the Great Inflation earlier, which I have refuted already, the same would happen. If the second oil crisis was managed - and indeed it was the case, shown following - that would strengthen the case that the Bank of Japan made a mistake the first time.

Figure 7.4 shows the interest rates (ODR and call rate) as well as the inflation rates (CPI and WPI) for the period from January 1976 to December 1980. The CPI inflation rate had fallen slowly to the 5 percent level by the end of 1979. The economy was back to normal from 1978 to the beginning of 1979. The economy showed the sign of a boom by the end of 1978. The dollar had a confidence crisis in mid-1978. The dollar decline (yen rise) 


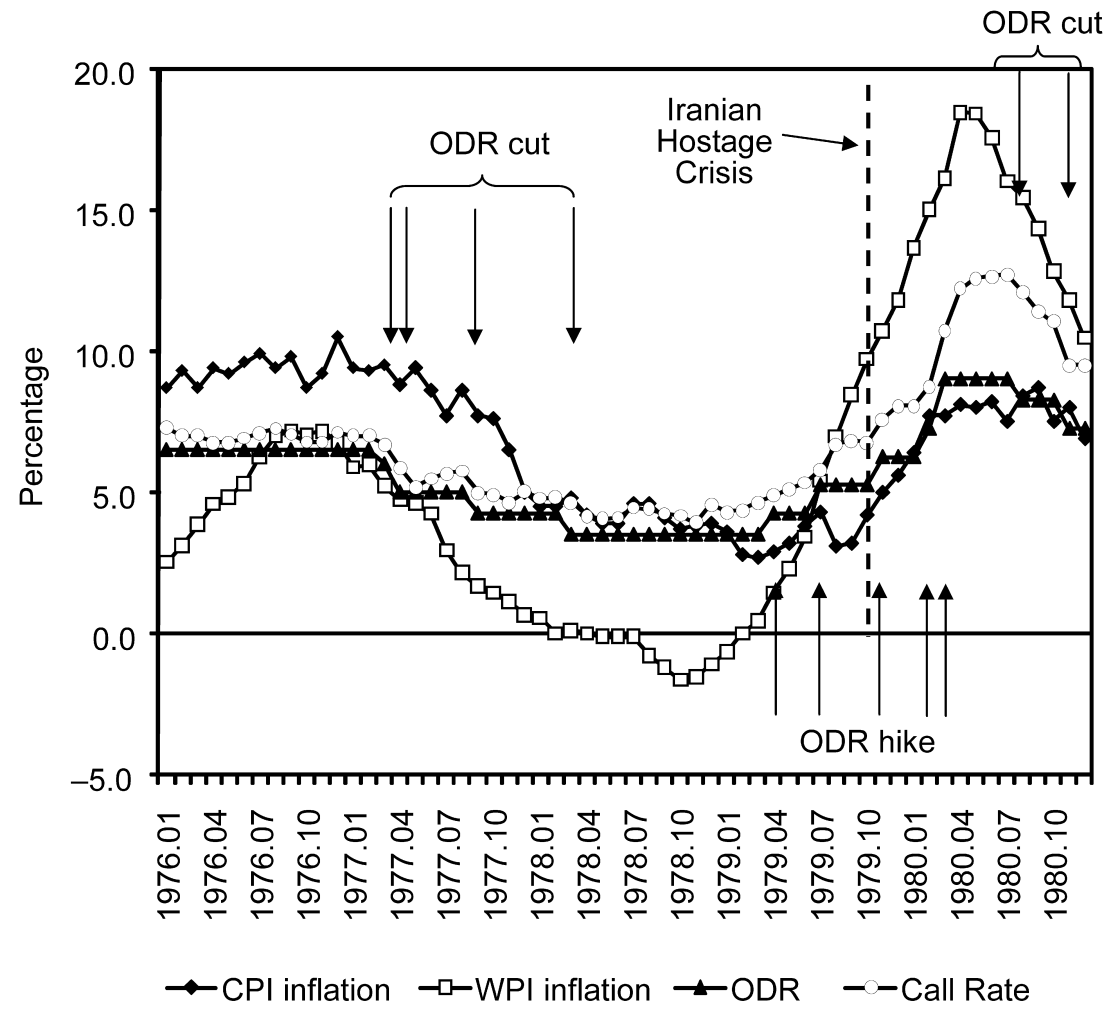

Fig. 7.4 Inflation during second oil crisis of 1979-1980

occurred for several months, but reversed after October 1978. This time, expansionary monetary policy was not taken. The WPI started to rise in the spring of 1979. This time, WPI movement was noted as a good forward indicator of CPI inflation. Although the CPI inflation rate was still stable at the 3 percent range, the ODR was hiked in April 17, 1979, and again in July 24, 1979, as shown in table 7.5. The WPI continued to rise, although CPI was still lagging behind during the summer of 1979. The oil prices started to rise in the summer, and accelerated further after the hostage crisis at the US Embassy in Iran in October 1979.

As the CPI inflation rate started to rise after October 1979, the Bank of Japan decided to raise the ODR further. The ODR was hiked again in November 2, 1979. The inflation rate continued to rise quickly.

The Bank of Japan sought and obtained an approval from the government to raise the policy interest rate, ODR, again in February and March of 1980. This was the first time that the Bank of Japan was able to raise the interest rate during the budget process. The bank could not respond quickly due to the moratorium during the budget process during the Great Inflation 


\begin{tabular}{lcc}
\hline $\begin{array}{l}\text { Date } \\
\text { yyyy.mm.dd }\end{array}$ & Change & New level \\
\hline 1977.03 .12 & -0.50 & 6.00 \\
1977.04 .19 & -1.00 & 5.00 \\
1977.09 .05 & -0.75 & 4.25 \\
1978.03 .16 & -0.75 & 3.50 \\
$\mathbf{1 9 7 9 . 0 4 . 1 7}$ & $\mathbf{0 . 7 5}$ & $\mathbf{4 . 2 5}$ \\
$\mathbf{1 9 7 9 . 0 7 . 2 4}$ & $\mathbf{1 . 0 0}$ & $\mathbf{5 . 2 5}$ \\
$\mathbf{1 9 7 9 . 1 1 . 0 2}$ & $\mathbf{1 . 0 0}$ & $\mathbf{6 . 2 5}$ \\
$\mathbf{1 9 8 0 . 0 2 . 1 9}$ & $\mathbf{1 . 0 0}$ & $\mathbf{7 . 2 5}$ \\
$\mathbf{1 9 8 0 . 0 3 . 1 9}$ & $\mathbf{1 . 7 5}$ & $\mathbf{9 . 0 0}$ \\
1980.08 .20 & -0.75 & 8.25 \\
1980.11 .06 & -1.00 & 7.25 \\
\hline
\end{tabular}

${ }^{\mathrm{a}}$ ODR increase during budget process.

episode, as described in the preceding section. Thus, the fact it was achieved brought tremendous joy to the Bank of Japan policymakers. The reason that the bank persuaded politicians and the Ministry of Finance was due to the high inflation experience of 1973 and 1974. The bank convinced the ministry and politicians of the importance of timely monetary policy actions. Many scholars, including Cargill, Hutchison, and Ito (1997), describe that the Bank of Japan achieved a de facto independence from the government by 1979 .

The CPI inflation rate was kept under 10 percent a year, and the real interest rate (call minus CPI inflation rate) remained positive. The effects of the second oil crisis were over by the end of 1980 .

\subsubsection{Quick Start of Tightening: April, July, and November 1979}

In January 1979, the governor mentioned that no more relaxing of monetary policy would come, and the policy stance was changed to "neutral." In March 1979, OPEC raised oil prices by more than 10 percent. The WPI started to increase sharply from January to March.

With the first sign of the WPI increase, the bank sought to raise the interest rate (Nakagawa 1981, 111-26). First, on March 20, Governor Morinaga mentioned that the Bank of Japan switched to a cautionary stance. In early April, Governor Morinaga told Prime Minister Ohira and the finance minister that the Bank of Japan wanted to raise ODR. They were in favor, but some other cabinet members were not in favor. Prime Minister Ohira understood the Bank of Japan position. The ODR hike was decided on April 16 (and implemented on April 17).

Nakagawa (1981, 116-26) also mentioned that the bank understood that early actions were needed due to lags in the monetary policy process. The WPI rose sharply from March to May 1979, mainly due to energy prices. 
Businesses complained of monetary tightening, arguing that monetary policy was ineffective against imported inflation. The Bank of Japan rebutted that the imported price increase would raise the CPI eventually and it would start the process of inflationary spiral, and that real activity was strong. In addition, Germany raised the interest rate at the end of March. The lessons of the 1972 to 1974 episode must have been learned and applied here.

The Economic Planning Agency disagreed with the Bank of Japan judgment, saying there were differences between the first oil crisis and 1979: the labor market was soft, money supply growth rate was lower, corporations were cautious, the utilization rate was lower, the exchange rate was floating, and the government was cautious. The Bank of Japan rebutted that it was worse due to a large amount of government bonds that had been issued between 1973 and 1979, the yen had depreciated, and oil prices began to rise early.

In July 1979, another ODR hike was realized. Nakagawa (1981, 126-34) explained this hike as follows. The OPEC raised the oil prices in July. At the Tokyo summit, restraining demand was agreed. Governor Morinaga met PM Ohira the day before flying to the Bank for International Settlements (BIS) meeting, proposed a rate hike, and got a nod immediately. Business activity was considered to be strong. The government, especially the Ministry of Finance, was cautious, and argued that the timing could be August or September. However, Governor Morinaga had gotten a nod from the prime minister on its personal relationship, and won the debate against the ministries.

The government still insisted that "in order to suppress aggregate demand" was an inappropriate reason for the rate hike. The Bank of Japan explained the action: "[D]emand-supply became tight. . . Money supply continues to increase and money tightening is not felt. Hence, in order to avoid making imported inflation into home-made inflation, it is absolutely necessary to raise the official discount rate" (Nakagawa 1981, 129). Upon agreement between the Ministry of Finance and the Bank of Japan, it was decided that the ODR be raised on July 23, and implemented July 24.

The ODR was further raised in November 1979. The WPI continued to rise (a large jump in September), the yen depreciated (223 yen/dollar at the end of September and 240 yen/dollar in October). The House of Representatives election took place on October 7. The Liberal Democratic Party lost many seats. Mr Ohira remained as Prime Minister, but only after a fierce fight and split voting in the House of Representatives (the so-called fortyday fight). The government was in chaos. The BOJ determined to raise ODR early, and this time there was no objection from the Ministry of Finance, but the bank waited until the next PM was to be determined (since there was no precedent of changing ODR during a general election or before a new cabinet was formed). The BOJ decided to raise ODR on November 1 and implemented it on November 2. 


\subsubsection{Interest Rate Hike in February and March 1980}

After the November 2 ODR hike, inflation worries continued. On November 4, 1979 the Iranian hostage crisis (the US Embassy was attacked and diplomats were taken hostage and were not released until January 1981) occurred, and the oil market conditions continued to tighten. On December 27, Afghanistan was invaded by the Soviets. As the political events multiplied, the oil prices continued to rise.

Domestic output activity was increasing, and steel and utilities prices were rising. In February 1980, the WPI inflation rate was near 20 percent. In view of these developments, newly appointed Governor Maekawa decided to raise the interest rate. However, this was the time of the budget process in the Diet. The interest rate hike was opposed by the Ministry of Finance on grounds of timing. I conjecture that the BOJ argued against the Ministry of Finance with the logic that the missed opportunity would result in a repeat of the high inflation of 1973 and 1974.

Governor Maekawa met Prime Minister Ohira in early February and requested an ODR hike. Prime Minister Ohira promised a reply within a week. Prime Minister Ohira gave a go-ahead in the replay. On February 18, 1980, it was decided to raise ODR by 1 percent, and was implemented a day later.

On March 18, the ODR was hiked again by 175 basis points. Between February and March, it was observed that the CPI started to rise sharply. The government also changed the priority toward fighting inflation. In the United States, the interest rate was raised to near 20 percent to fight inflation in early $1980 .{ }^{13}$

In the end, Japan fared well in the second oil crisis. The CPI inflation rate never reached 10 percent, and the real interest rate measured by call rate over the CPI inflation rate remained positive. The worst of inflation was over by the summer of 1980, and the ODR was lowered in August and November 1980. By the end of 1980, the WPI inflation rate came down to 10 percent, and the CPI inflation rate decelerated to 7 percent.

"Lessons" of 1973 and 1974 were fully utilized by the BOJ to persuade the Ministry of Finance and the Prime Minister for early actions on monetary tightening. Raising ODR twice during the budget process was a strong indication that the BOJ had achieved de facto independence. However, still it relied on the understanding of the prime minister, and the trust between governor and the prime minister, rather than a legal framework. Credibility and de facto independence seemed to be subject to who was governor and who was prime minister. This precarious relationship would continue until the revision of the Bank of Japan Law in 1998.

13. Paul Volcker took over as chairman of the Federal Reserve Board in 1979 to fight inflation with a determined manner. 


\subsection{Econometric Analysis}

\subsubsection{Purpose}

In the narrative, it was established that the Bank of Japan made a mistake prior to and during the first oil crisis, while the bank skillfully managed the second oil crisis. In this section, econometric analysis will be employed to quantify this narrative. A modified Taylor rule equation during the period when the Bank of Japan was considered to be successful will be estimated, and the fitted values with estimated coefficients from the well-run period will be applied to the presumed-mistake periods. ${ }^{14}$

The Taylor rule (and its variants) should be used with care when it is used as more than a description of the response function of the central bank or for normative interpretations. ${ }^{15}$ If it is to be used in the normative spin, it is absolutely important to find a time period when conduct and consequences of monetary policy conduct are impeccable.

In Japan's case, after the mistake of 1972 to 1974, the Bank of Japan gained de facto independence by reminding the government of the sorry episode in 1972 and 1973. ${ }^{16}$ The Bank of Japan successfully lowered the inflation rate from 10 percent in 1975 to 2 percent in the early $1980 \mathrm{~s} .{ }^{17}$ Once the inflation rate was brought down to a level near 2 percent, the monetary policy entered a happy state of maintaining a low and stable inflation rate. Monetary policy during the economic boom toward the end of the 1980s was a bit controversial in retrospect, because it allowed an asset price bubble to form, which later burst. However, in the sense of CPI price stability, the second half of the 1980s had a good performance. In the 1990s, there was some question raised by several authors whether loosening of monetary policy after the bubble burst (1991 and 1992) was quick enough to prevent a sharp decline in output after 1993. ${ }^{18}$ However, the Bank of Japan had controlled the interest rate in an attempt to stabilize inflation and output until the financial system fell into a serious crisis, with some failure of medium-size regional bank, and the official discount rate being lowered to 0.5 percent in September 1995. Soon after the interest rate was lowered to 0.5 percent in September 1995, the Bank of Japan lost its grip on infla-

14. For Taylor rule, see Clarida, Galí, and Gertler (1999) and Taylor (1999), to name a few. See Jinushi, Kuroki, and Miyao (2000); Kuttner and Posen (2004); and Ahearne et al. (2002) for application of the Taylor rule to the Japanese case.

15. Taylor (2009, FAQ section) insists that the Taylor rule is normative from the beginning. Others, including Orphanides (2003a, 2003b, 2003c); Clarida, Galí, and Gertler (1998, 1999); and Ito and Mishkin (2006) are rather cautious on the normative interpretation.

16. See Cargill, Hutchison, and Ito (1997) for such an interpretation.

17. See, for example, Friedman (1985b) and Ito (1992, ch. 5).

18. See Ahearne (2002); Clouse et al. (2000); Ito and Mishkin (2006); Jinushi, Kuroki, and Miyao (2000); Kuttner and Posen (2004) for the discussion of Japan's monetary policy in the early to mid-1990s. 
tion, partly due to the zero bound of the nominal interest rate and partly due to near deflation.

With the abovementioned discussions in mind, I take the period from January 1982 to December 1995 as a benchmark period that can be regarded as a successful period in CPI inflation stability. The benchmark Taylor rule will be estimated for this period.

Several provisos should be mentioned at this point. First, the policy rate was the official discount rate (ODR), and many market interest rates were tied to the ODR. Second, there were monetary policy measures other than the policy rate. The so-called "window guidance" - constraints on bank lending by moral suasion - was playing a major role. The reserve requirement was also used. Hence, the interest rate was not the only variable that represented monetary policy. Third, many market infrastructures and economic structures went through changes during the 1970s and 1980s. Financial liberalization particularly progressed in the second half of the 1980s. Attempts are made to take into account these issues, but treatment is admittedly far from perfect.

After examining the estimated coefficients and the deviations of fitted value from actual value within the sample, the out-of-sample backcasting will be conducted to see whether the Bank of Japan would have behaved differently in the 1970s. In particular, the mistake of monetary policy creating the Great Inflation of 1972 to 1974 will be examined in light of the estimated Taylor rule of 1982 to 1995 . This exercise will answer the following question: Suppose that the Bank of Japan in 1972 to 1974 (the "mistake" years) had reacted to macro variables in the manner they had in 1982 to 1995 . How much would the counterfactual interest rate have been hiked compared to the actual interest rate? If it could be shown that the counterfactual interest rate would have been much higher than actual, then the prudent Bank of Japan à la 1982 to 1995 would have mitigated the inflation problem in 1972 to 1974 .

The typical Taylor rule equation is as follows:

$$
i_{t}=r^{f}+\pi_{t}+\beta_{\pi} \cdot\left(\pi_{t}-\pi^{*}\right)+\beta_{y} \cdot\left(y_{t}-y^{*}\right),
$$

where $i_{t}$ denotes the nominal policy interest rate, $r^{f}$ the natural real interest rate, $\pi^{*}$ the target inflation rate, $\pi_{t}$ is the inflation rate, and $y_{t}-y^{*}$ is the output gap. In the original Taylor (1993), both $\beta$ were assumed to be 0.5 , and $r^{f}$ and $\pi^{*}$ were both assumed to be 2 . Here, as in the literature, $\beta$ will be estimated using data in the benchmark period. In the implementation of estimating this equation, the following specification is used:

$$
i_{t}-\pi_{t}=r^{f}+\beta_{\pi} \cdot\left(\pi_{t}-\pi^{*}\right)+\beta_{y} \cdot\left(y_{t}-y^{*}\right)+\varepsilon_{y} .
$$

The left-hand side becomes the real interest rate at time $t$. There are several departures from the usual Taylor rule regression in the literature. First, since the decision making is done on a monthly basis (rarely two policy rate 
changes in the same month), a monthly model is highly recommended. The GDP gap will not be available on the monthly basis, so that the industrial production will be used as a measure of output. The industrial production gap will be defined and used in place of GDP. Second, efforts will be made to obtain data that were available at the time of decision making, although the data used in the regression are not exactly the real time data. Third, since the equilibrium real rate $r^{f}$ is difficult to calculate, the equilibrium nominal rate is to be estimated as a constant term of the regression model.

\subsubsection{Data}

Several variables have to be carefully defined for the Taylor-rule type econometric application. First, the output gap (output deviation from its potential) and inflation gap (inflation deviation from its target) have to be defined in the spirit of "real-time data" - that is, data that were known at the time the policy was decided. The importance of using real-time data is particularly emphasized by Orphanides (2003a, 2003b, 2003c). For example, use of the original data at time $t$ should be used instead of later revisions, including base year change or preliminary to final. Second, any detrending, or estimating and taking out potential output, should be carried out with the data only up to time $t$. Third, since data collection and data disclosure takes time, at the time of monetary policy decision in month $t$, available data of Industrial Production and CPI are not those of month $t$, but either month $t-1$ or even $t-2 .{ }^{19}$ Although official data may be available only for $t-2$, various other economic variables can be used to guess what would be announced later. ${ }^{20}$ So, we assume that the data that the Bank of Japan knows at month $t$ would be Industrial Production and CPI of month $t-1$.

Because we attempt to build a monthly model, GDP cannot be used as a variable for output gap. In place of GDP, Industrial Production will be used. The base year of Industrial Production is changed every five years. If we had picked up data from the present database, it would be a series of current estimation methods, and different from the variable that was known at the time of decision making in the 1970s to the 1990s. Therefore, the original Industrial Production data set is collected from historical series that were available at the time of decision making. ${ }^{21}$ For the output gap

19. The Policy Board Meetings (in charge of monetary policy decisions) became regularly scheduled meetings (with the meeting dates preannounced) under the revised Bank of Japan Law, which took effect in April 1998. Earlier, monetary policy meetings were called upon when needed. However, we assume that even without a prescheduled meeting, the bank staff makes the decision to call a meeting or not at least every month.

20. The CPI of month $t$ becomes available in month $t+2$. One option is to use the CPI inflation rate on the right-hand side of the variable of two months ago. However, with information of CPI of Tokyo Area, which is announced in month $t+1$, one can guess the national CPI with some accuracy before their disclosure. Therefore, the CPI on the right-hand side is the inflation rate of $t+1$.

21. Admittedly, this is not "genuine" real-time data, since original documents, such as every issue of the Monthly Report of the Bank of Japan, are not checked against the old database. The minutes of the monetary policy meetings were not kept before 1998 . 
$y_{t}-y^{*}$, a deviation of the Industrial Production from its linear trend, which is known at time $t$, is used. ${ }^{22}$ Obviously the future path of industrial production is not known, and the trend must be estimated using only the past date at the time of decision making. The industrial production gap was estimated from January 1971 to December 2008.

For the inflation measure $(\pi)$, the year-on-year change of headline CPI is used. ${ }^{23}$ The base year of the CPI and weights of goods and services in the consumption basket are revised every five years in Japan. As CPI of a new base year becomes available, the Bank of Japan and the government starts using the new CPI for their decision making. The real-time CPI is constructed by choosing the headline CPI of the base year that was in place. ${ }^{24}$

The target inflation rate is also difficult to determine. The inflation rate during the 1960s was much higher than the later period. It is assumed that the target inflation rate, $\pi^{*}$ was 4 percent from January 1971 to December 1977. As the Bank of Japan became serious in lowering the inflation rate in 1978 by adopting the monetary aggregate "forecast" (see Ito 1989), it is assumed that the target rate was gradually ( $1 / 24$ percentage point a month) lowered from 4 percent in December 1977 to 2 percent by December 1981. The target inflation rate was again lowered gradually from 2 percent in December 1992 to 1 percent in December 1998, and has stayed at 1 percent since then.

\subsubsection{Estimation}

Based on the previous discussion, the equation to be estimated is the following:

22. The output gap is the residual in the log-linear trend regression using data of the preceding ten years $[t-119, t]$. Extract the residual at $t$. By multiplying by 100 , the percentage deviation from the trend line is stored. Then, repeat the procedure (i.e., rolling regression) from January 1971 to December 2008.

23. The headline inflation was most often mentioned in the 1970s, 1980s, and 1990s. When the exit condition from quantitative easing was mentioned in March 2001, it was defined in the CPI (excluding fresh food, but including energy prices). Since the 2000s are not a period for analysis in this chapter, the headline CPI is used throughout. Otherwise the inflation rate to be analyzed should be switched from headline inflation to CPI, excluding food, of May 2001 with the change in the base year as well. Another potential adjustment that is ignored in this chapter is the introduction of consumption tax (a form of value added tax, or VAT) in April 1989 and tax rate increase in April 1997. When the 3 percent consumption tax was introduced in April 1989, some of excise and other indirect taxes were abolished, so that the net effect on the consumer prices were much less than 3 percent. Ito and Mishkin (2006) argued that the year-on-year inflation rate due to consumption tax was 1.3 percent for April 1989 to March 1990, and 1.6 percent for April 1997 to March 1998. However, no adjustment is made in this chapter for consumption tax increases, on the assumption that the Bank of Japan was alert on inflation even due to the consumption tax increases, as inflation due to consumption tax increases may trigger second round inflation.

24. As in Industrial Production, what we collected from old base-year CPI may not be genuine real-time CPI. Original documents at the time of monetary policy board meeting were not checked against our data. Minutes were not kept, and often the meeting was called suddenly. In this sense, what we call real-time data here are what we believe to the best approximation of the real-time data. 
Table 7.6

Monthly Taylor rule, 1982-1995

\begin{tabular}{lcccc}
\hline \multicolumn{4}{c}{ Equation (1): Sample: 1982M01 } & 1995M12 \\
\cline { 2 - 4 } & Coefficient & Std. error & $t$-statistic & Prob. \\
\hline $\mathrm{C}$ & 3.723 & 0.130 & 28.54 & 0.000 \\
$\pi_{t}-\pi_{t}^{*}$ & 0.336 & 0.165 & 2.03 & 0.044 \\
$y_{t}-y_{t}^{*}$ & 0.127 & 0.021 & 5.97 & 0.000 \\
$R^{2}$ & 0.366 & & & \\
\hline
\end{tabular}

$$
i_{t}-\pi_{t-1}=c+\beta_{\pi} \cdot\left(\pi_{t-1}-\pi_{t}^{*}\right)+\beta_{y} \cdot\left(y_{t-1}-y_{t}^{*}\right)+\varepsilon_{t},
$$

where the constant term $c$ will be interpreted as the long-run real interest rate. The inflation and industrial production are lagged once due to observation lag for the central bank. Since the inflation rate is defined as year-onyear, there will be serial correlation in the residuals. generalized methods of moments (GMM) is used to estimate equation (1). ${ }^{25}$

The sample period of estimation is from January 1982 to December 1995. The choice of this time period is discussed earlier in this section.

Table 7.6 shows the estimation results. Both inflation gap and output gap have statistically significant estimates with correct sign. The magnitude of coefficients are smaller than the original Taylor assumption of 0.5 . If the inflation rate rises 1 percentage point, the nominal interest rate rises 1.34 percentage points, since the "real" interest rate responds by 0.34 percentage point. If the output gap moves positively (overheating) by 1 percentage point, then the nominal interest rate rises by 0.127 percent, assuming no change in the inflation rate.

Figure 7.5 shows the actual and fitted values in the sample period, and their difference, the residual of the equation. Assuming that the fitted value can be interpreted as a desirable path, the figure suggests the following interpretation: the monetary policy was too tight (actual > fitted) in 1985 and 1986, while the monetary policy was too loose in 1988 and 1989. The two years of 1988 and 1989 are known to be the last stage of the real estate bubble. Several authors have suggested that the Bank of Japan made a mistake in these years by allowing the bubble to form, thus the asset prices should have been included in deciding monetary policy. (See Okina and Shiratsuka 2002, 2004). However, as figure 7.5 suggests, even a plain CPI Taylor rule would have flagged loose monetary policy as being too loose in these two years.

25. For the instruments, $c, \pi_{t-2}-\pi^{*}, y_{t-2}-y^{*}$, dyen ${ }_{t-1}$, doil $t_{t-1}$ are used, where dyen is $_{t}$ the year-on-year change of the yen/dollar rate in month $t$ and doil $t_{t}$ is the year-on-year change of the oil prices in month $t$. 


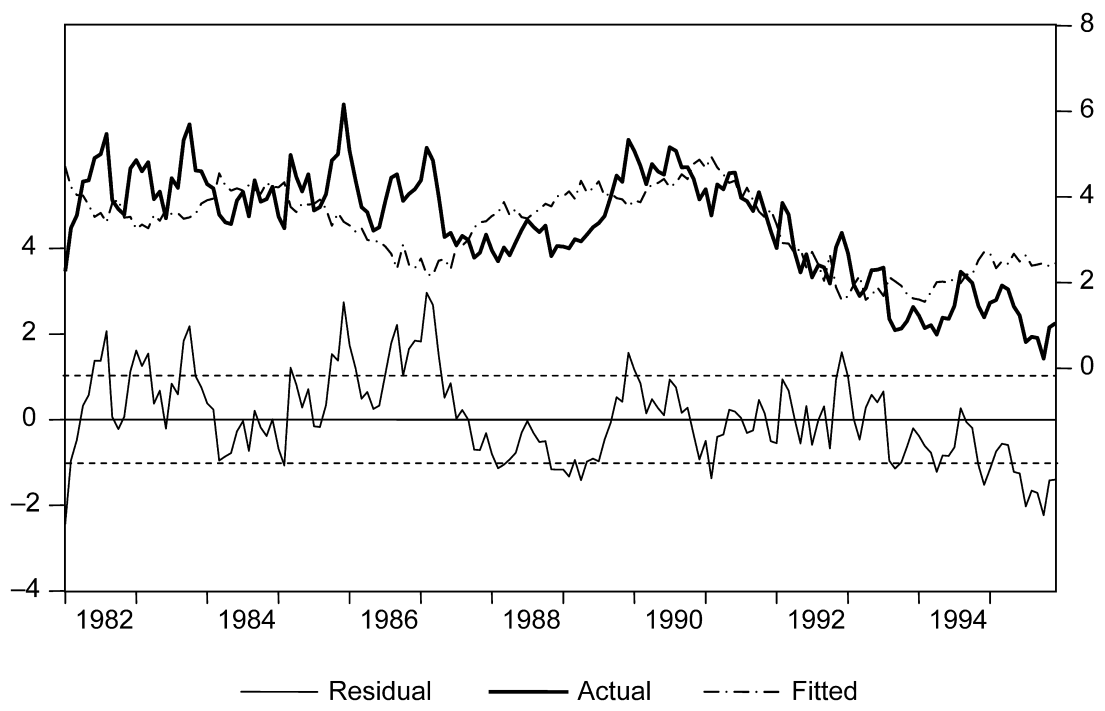

Fig. 7.5 Actual value, fitted value, and residual: call $-\pi_{t-1}$

\subsubsection{Out of Sample Backcasting}

Now that we have reasonable estimates of the modified Taylor rule for the period in which the monetary policy can be regarded as desirable on average, we can evaluate the monetary policy of other periods in question. We are particularly interested in the "mistake" in the early 1970s, when the inflation rate rose above 20 percent. Using the estimated coefficients of table 7.6, and then plugging in the data of 1972, we obtain the counterfactual call rate during the period in question. ${ }^{26}$ Figure 7.6 shows the actual and counterfactual nominal call rate. Obviously, the counterfactual nominal rate (i.e., the desirable call rate) would have been much higher than the actual call rate. The desirable interest rate would have been around 36 percent when the actual rate was 12 percent. This exercise shows numerically what we have already established in the narrative. In the year after the collapse of the Bretton Woods system, monetary policy made a mistake. When the first oil crisis came, the inflation rate was already high. With the additional shock of oil price increases, the inflation rate rose sharply, exceeding 20 percent. The magnitude of the mistake was more than 20 percentage points in the call rate.

One should be careful in interpreting these findings. The path of the counterfactual call rate is not a desirable path. If the desirable path of $1972 \mathrm{had}$ inflation rate, the counterfactual nominal interest rate is obtained. 


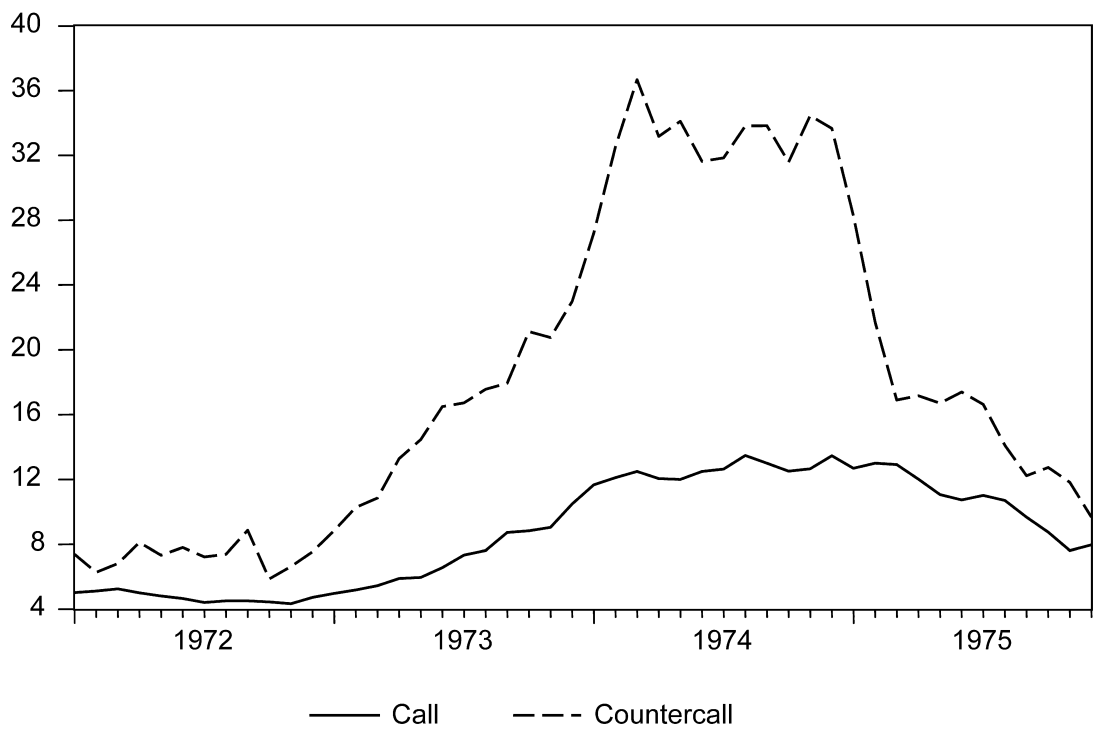

Fig. 7.6 Counterfactual 1972-1975

been implemented, then the actual inflation rate would have been lower, so that the interest rate in 1973 would not have been so high. The desirable rate should be interpreted as the rate that, given the actual history up to $t-1$, would have been the desirable call rate in month $t$.

Figure 7.7 shows the similarly generated desirable rate for the period of 1978 to 1982 , the period that encompasses the second oil crisis. This shows that the counterfactual interest rate was not much different (up to 1.5 percentage points) from the actual rate in 1979 to 1980, the oil crisis years. This confirms the narrative that the second oil crisis was handled much better than the first one.

\subsection{Concluding Remarks}

This chapter investigated the great inflation of Japan, 1973 to 1974, when the CPI inflation rate reached almost 30 percent a year, and the WPI inflation rate higher than that. The period coincided with the first oil crisis. Close examinations revealed that easing in 1971 and 1972 went too far, stimulating the economy too much, and tightening in 1973 came too little, too late. The CPI inflation rate was already above 10 percent when the Middle East War broke out in October 1973. The oil price increase and the sense of panic for not obtaining the energy resources caused further increases in prices.

The reasons for too much easing and too little tightening from 1971 to 1973 include several political economy reasons as well as economic 


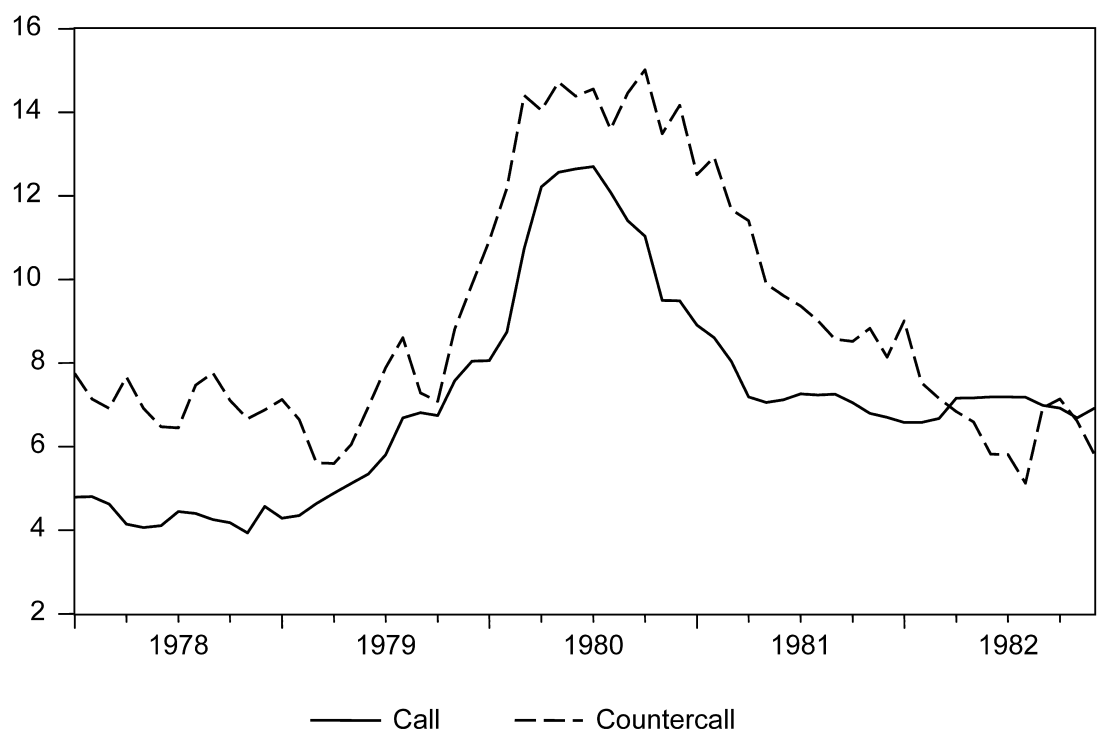

Fig. 7.7 Counterfactual 1978-1982

reasons. First, too much attention and efforts were devoted to prevent the yen appreciation under the Smithsonian regime. Some politicians openly voiced preference to inflation over nominal appreciation of the yen. Second, the Bank of Japan was not independent from the government. The prime minister exerted pressure on the bank to lower the interest rate or to prevent the interest rate hike. The timing of implementation was also influenced by the political agenda and schedule. It was commonly thought that the interest rate could not be changed during the budget discussion in the Diet; that is, December to March. Third, the Bank of Japan did not fight the government enough to push for the right decisions. Self-restraints were applied not to cause conflict against the Ministry of Finance.

The second oil crisis was handled much better than the great inflation experience. The CPI remained lower than 10 percent, and the real interest rate was kept positive. The interest rate was raised as soon as the WPI started to increase in 1978. The ODR was raised even when the budget was still being discussed in the Diet. The bank gained de facto independence using the logic that without swift actions, the mistake of high inflation would be repeated. Prime Minister Ohira was also quite respectful to Governor Maekawa for the bank's judgment and decisions.

The modified (monthly) Taylor rule was specified and estimated using the data of the period from January 1982 to December 1995, a period of relative success in achieving low and stable inflation rate. Then the estimate 
coefficients of the equation were applied to the data of the mistake period, 1972 to 1975 . The desirable interest rate would have been some 20 percentage points higher than the actual rate. When the same procedure was applied to the second oil crisis period, 1978 to 1982, then it was shown that the desirable rate would not have been much different from the actual rate. The exercise confirms the conclusion of the narrative. The roots of the Great Inflation can be found well before the onset of the first oil crisis, which took place in October 1973. The modeling analysis implies that the interest rate was way too low before and after October 1973.

\section{References}

Ahearne, Alan, Joseph Gagnon, Jane Haltmaier, and Steve Kamin. 2002. "Preventing Deflation: Lessons from Japan's Experience in the 1990s." Board of Governors of the Federal Reserve System, International Finance Discussion Papers, no. 729.

Bank of Japan. 1975. “On the Importance of Money Supply in Japan.” [In Japanese.] Monthly Review, Research and Statistics Bureau July:1-11.

_. 1986. Nihon Ginko Hyakunenshi [One-Hundred Year History of the Bank of Japan, volume 6]. Tokyo: Bank of Japan.

- 1988. "On the Recent Behavior of the Money Supply." [In Japanese.] Monthly Review, Research and Statistics Bureau February (1988): 1-24.

Cargill, Thomas F., Michael M. Hutchison, and Takatoshi Ito. 1997. The Political Economy of Japanese Monetary Policy. Cambridge, MA: MIT Press. Press.

Clarida, Richard, Jordi Galí, and Mark Gertler. 1998. "Monetary Policy Rules in Practice: Some International Evidence.” European Economic Review 42:1033-67.

_ 1999. "The Science of Monetary Policy: A New-Keynesian Perspective." Journal of Economic Literature 37:1661-707.

Clouse, James, Dale Henderson, Athanasios Orphanides, David Small, Peter Orphanides, and Peter Tinsley. 2000. "Monetary Policy When the Nominal ShortTerm Interest Rate is Zero." Finance and Economics Discussion Series, 2000-51. Washington, DC: Board of Governors of the Federal Reserve System.

Friedman, Milton. 1985a. "The Fed's Monetarism Was Never Anything But Rhetoric." Letters to the Editor, Wall Street Journal, December 18.

.1985b. "Monetarism in Rhetoric and in Practice." In Monetary Policy in Our Times, edited by Albert Ando, Hidekazu Eguchi, Roger Farmer, and Yoshio Suzuki, 15-28. Cambridge, MA: MIT Press.

Hetzel, Robert L. 1999. "Japanese Monetary Policy: A Quantity Theory Perspective." Federal Reserve Bank of Richmond Economic Quarterly 85 (Winter): 1-25.

Ito, Takatoshi. 1989. "Is the Bank of Japan a Closet Monetarism? Monetary Targeting in Japan, 1978-1988." NBER Working Paper no. 2879. Cambridge, MA: National Bureau of Economic Research.

1992. The Japanese Economy. Cambridge, MA: MIT Press.

1997. "The Long-Run Purchasing Power Parity for the Yen: Historical Overview." Journal of the Japanese and International Economies 11:502-21. 
Ito, Takatoshi, and Frederic S. Mishkin. 2006. "Two Decades of Japanese Monetary Policy and the Deflation Problem." In Monetary Policy with Very Low Inflation in the Pacific Rim, edited by T. Ito and A. Rose, 131-93. Chicago: University of Chicago Press.

Jinushi, Toshiki, Yoshihiro Kuroki, and Ryuzo Miyao. 2000. "Monetary Policy in Japan since the Late 1980s: Delayed Policy Actions and Some Explanations." In Japan's Financial Crisis and Its Parallels to US Experience, edited by Mikitani and Posen, 115-48. Washington, DC: Institute for International Economics.

Komiya, Ryutaro. 1976. "Reasons for Inflation in 1973-74." [Original in Japanese: "The Showa 48-49 Inflation on Genin."] University of Tokyo, Keizaigaku Ronshu 42 (1): 2-40.

1988. The Japanese Economy: Trade, Industry, and Government. Tokyo: University of Tokyo Press.

Komiya, Ryutaro, and Kazuo Yasui. 1984. "Japan's Macroeconomic Performance since the First Oil Crisis: Review and Appraisal." Carnegie-Rochester Conference Series on Public Policy 20:69-114.

Kuttner, Kenneth N., and Adam S. Posen. 2004. "The Difficulty of Discerning What's Too Tight: Taylor Rules and Japanese Monetary Policy." North American Journal of Economics and Finance 15:53-74.

Nakagawa, Yukitsugu. 1981. On Monetary Policy: Personal Experience at the Bank of Japan. [Original in Japanese: Taikenteki Kinyu Seisaku Ron: Nichigin no Mado kara.] Tokyo: Nihon Keizai Shinbunsha.

Oi, Hiroyuki, Shigenori Shiratsuka, and Toyoichiro Shirota. 2004. "On Long-Run Monetary Neutrality in Japan." Institute for Monetary and Economic Studies, Bank of Japan, Monetary and Ecnomic Studies 22 (3): 79-113.

Okina, Kunio, and Shigenori Shiratsuka. 2002. "Asset Price Bubbles, Price Stability, and Monetary Policy: Japan's Experience." Bank of Japan, Monetary and Economic Studies October:35-76.

2004. "Policy Commitment and Expectation Formation: Japan's Experience under Zero Interest Rates." North American Journal of Economics and Finance 15:75-100.

Orphanides, Athanasios. 2003a. "Historical Monetary Policy Analysis and the Taylor Rule." Journal of Monetary Economics 50:983-1022.

. 2003b. "Monetary Policy Evaluation with Noisy Information." Journal of Monetary Economics 50:605-31.

. 2003c. "The Quest for Prosperity without Inflation." Journal of Monetary Economics 50:633-63.

Shizume, Masato. 2002. "Economic Developments and Monetary Policy Responses in Interwar Japan: Evaluation Based on the Taylor Rule.” Bank of Japan, Monetary and Economic Studies 20 (3): 77-116.

Suzuki, Yoshio. 1985. "Japan's Monetary Policy over the Past 10 Years.” Bank of Japan, Monetary and Economic Studies 3 (2): 1-10. Press.

Taylor, John B. 1993. "Discretion versus Policy Rules in Practice." Carnegie-Rochester Conference Series on Public Policy 39:195-214.

. 1999. "A Historical Analysis of Monetary Policy Rules." In Monetary Policy Rules, edited by J. B. Taylor, 319-44. Chicago: University of Chicago Press.

2009. Getting off Track: How Government Actions and Interventions Caused, Prolonged, and Worsened the Financial Crisis. Stanford: Hoover Press. 